This item was submitted to Loughborough's Research Repository by the author.

Items in Figshare are protected by copyright, with all rights reserved, unless otherwise indicated.

\title{
The tyranny of transnational discourse: 'authenticity' and Irish diasporic identity in Ireland and England
}

PLEASE CITE THE PUBLISHED VERSION

http://dx.doi.org/10.1111/j.1469-8129.2011.00534.x

\author{
PUBLISHER \\ (C) ASEN/Blackwell
}

VERSION

AM (Accepted Manuscript)

\section{PUBLISHER STATEMENT}

This work is made available according to the conditions of the Creative Commons Attribution-NonCommercialNoDerivatives 4.0 International (CC BY-NC-ND 4.0) licence. Full details of this licence are available at: https://creativecommons.org/licenses/by-nc-nd/4.0/

\section{LICENCE}

CC BY-NC-ND 4.0

\section{REPOSITORY RECORD}

Scully, Marc D.. 2019. "The Tyranny of Transnational Discourse: 'authenticity' and Irish Diasporic Identity in Ireland and England”. figshare. https://hdl.handle.net/2134/25412. 


\title{
The tyranny of transnational discourse?: ‘Authenticity' and Irish diasporic identity in Ireland and England.
}

\author{
Marc Scully \\ The Open University
}

\begin{abstract}
Through the prism of current state discourses in Ireland on engagement with the Irish diaspora, this article examines the empirical merit of the related concepts of diaspora and transnationalism. Drawing on recent research on how Irish identity is articulated and negotiated by Irish people in England, the article suggests a worked distinction between the concepts of 'diaspora' and 'transnationalism'. Two separate discourses of authenticity are compared and contrasted, the first resting on a conceptualisation of Irish identity as transnational, and the other as diasporic. It is argued that knowledge of contemporary Ireland is constructed as sufficiently important that claims on diasporic Irishness are constrained by the discourse of authentic Irishness as transnational. How this effects the identity claims of second-generation Irish people, the relationship between conceptualisations of Irishness as diasporic within Ireland and 'lived' diasporic Irish identities, and implications for State discourses of diaspora engagement are discussed.
\end{abstract}

\section{Keywords:}

Diaspora; transnationalism; Irishness in England; national identity; second-generation identity; migrant communities. 


\section{Introduction}

Due to the proximity between the two countries, the constant nature of the migration between them, and the ways in which Irish and English national identity have been historically oppositionally arranged, any discussion of Irish identity in England must consider the contours of how Irishness is contemporaneously imagined in Ireland. It is the contention of this paper that changing perspectives on Irish identity in Ireland shape the ways in which Irishness in England can be claimed and expressed. Irishness in England represents a confrontation between diasporic and transnational expressions of Irishness - through tracing such contestation in the talk of Irish people in England, further insights on the nature of diaspora and transnationalism can be established. In order to establish why an empirical perspective on the contested nature of Irishness in England is necessary, I will first outline how, despite the growing popularity of the concept of an Irish diaspora, state and public discourses in Ireland gloss over the multifaceted nature of diasporic identification among individual Irish people outside Ireland.

\section{The Irish nation-state and the Irish diaspora}

The conceptual confusion caused by the proliferation of the term 'diaspora' in recent years has caused theorists such as Brubaker (2005) to suggest that the term has lost its conceptual usefulness in being applied to 'any and every population category that is to some extent dispersed in space' (p.3). This proliferation is not confined to academia, with the term 'diaspora' becoming more common in public discourse, and increasingly as part of the governing language of nation-states. This is particularly the 
case with regard to the relationship between the Irish nation-state and the Irish diaspora, and the evolution of the dominant discourse surrounding 'diaspora' in Ireland is illustrative of how the popularisation of the term can lead to some of its subtler implications being lost.

Popular and academic interest in the concept of an Irish diaspora increased exponentially within and outside Ireland throughout the 1990s, with the publication of such books as Donald Harman Akenson's (1993) The Irish Diaspora, Tim Pat Coogan's (2000) Wherever Green is Worn and Patrick Bishop's (1999) The Irish Empire, which accompanied a television series of the same name. This rise in interest coincided with the theoretical turn to diaspora as a means of deconstructing the essentialist tendencies of national identity. Many theorists utilised the notion of diaspora and diasporic identities as a means of articulating and promoting antiessentialist accounts of identity formation, as aligned with the growing consensus of identities as fragmented and socially constructed. It was argued that looking through the prism of diaspora allows hybrid, multi-ethnic, provisional and contingent identities and multiple belongings to be articulated in a way that is not possible through more conventional readings of the national. Diaspora, then, when conceptualised as a means of identification comes to signify more than a scattered people, but signifies a de-territorialised, liminal means of speaking about identity and identity processes (Bhabha, 1990, 1994; Brah, 1996; Clifford, 1994; Gilroy, 1997).

In the Irish context, this emphasis on diaspora as representing a deterritorialised form of national identity was echoed by then-President Mary Robinson who made 'Cherishing the Diaspora' a central theme of her presidency. In a 1995 address to the 
Houses of the Oireachtas (the Irish Parliament), she argued that it was 'an added richness of our heritage that Irishness is not simply territorial' and that the Irish diaspora highlighted the diverse nature of Irish identity both within and beyond the island of Ireland. She invoked diasporic Irishness as an example of a more progressive Irishness and one that could instruct Irish society within Ireland in values of 'diversity, tolerance and fair-mindedness' later emphasising the need to 'accept that in their new perspectives may well be a critique of our old ones' (Robinson, 1995).

Breda Gray $(2000 ; 2002)$ in situating this speech among others as forming an emerging discourse of diaspora in 1990s Ireland, contends that this diasporic identity was characterised in terms of pluralism, hybridity and newness. The thesis that the concept of diaspora could be useful in articulating a more progressive Irishness and disrupting normative national narratives by deconstructing hegemonic, sedentary norms of Irish nationhood and culture was taken up by a number of academics and commentators and thus gained currency in Irish intellectual circles (Mac Éinrí \& Lambkin, 2002). To a certain extent, this was predicated upon the notion of Ireland as an almost irredeemably conservative nation and that 'those most likely to foment change left, whether voluntarily or not' (Cullen, 1999, p. 75). The diaspora was romanticised through a discourse of the 'bright and the beautiful taking off' and the staying population being represented as passive in contrast to migrant initiative (Gray, 2004). For those who might have wished to see a more progressive Irish society, economy and polity, the diaspora simultaneously represented a lost opportunity, and a possible mechanism for change. 
Gray critiques this 'progressive' discourse by illustrating the disjuncture between the theoretical possibilities of diaspora and practice; for example, plans to extend limited voting rights to migrants quickly ran aground in the face of widespread public opposition. Also, the 'lived' diaspora residing outside Ireland often 'failed' to live up to the idealised version of the theorised diaspora. In contrast to the picture portrayed of the diaspora as diverse, tolerant, fair-minded, forward-looking and pluralistic, it became apparent that many diasporic communities took pride in a form of cultural maintenance more associated with 1950s Ireland, something that was at odds with contemporary Ireland's view of itself as a modern nation (Gray, 2002). Therefore, in acknowledging the Irish diaspora, contemporary Ireland has entered into a somewhat contradictory and troubled relationship with it. Depending on the context, the diaspora is identified simultaneously with discourses of Irishness as progressive and modern and discourses of Irishness as old-fashioned and culturally static. There is also a problematic tendency to conceptualise the Irish diaspora as a homogenous 'community', at times conflated with 'Irish America', as opposed to a phenomenon that is fundamentally heterogeneous, global and fractured by class, gender and other deep conflicts of interest (Akenson, 1993; Hickman, 2002).

In recent years, and arguably as a response to the more troubling and confrontational aspects of diaspora, there has been a tendency to gloss over the fractured nature of the Irish diaspora in favour of an imagined global economic community. This may have its roots in the romanticised reading of diaspora that dovetailed conveniently with governmental discourses that arose in the 1980s that sought to alleviate blame for the increase in youth emigration at the time, by portraying this migration as qualitatively different from past migrations arising out of hardship. Rather, this new generation of 
migrants were portrayed as being middle-class, well-educated and inclined to leave Ireland in search of adventure and experience, rather than being forced to leave by lack of employment within Ireland itself. Echoing this, Bowden (2010) has argued that the popularity of the term 'diaspora' and its use in contemporary government discourse has led to it becoming the sanitised version of the word 'emigration', and a way of glossing over the fact that Irish emigration figures are rising rapidly once more. This reading of diasporans as economic entrepreneurs has gradually permeated state discourses around how best to engage with the Irish diaspora.

As such, while there have been a number of State-led initiatives encouraging engagement with the diaspora, the diaspora itself has been conceptualised as a relatively homogenous extension of the Irish nation in other national climes, or as an 'emigrant state'. This is occasionally manifested in suggestions that the State has a level of responsibility to its citizens living in straitened circumstances abroad; the Irish government provides funding for welfare groups in other countries working with destitute Irish, who are largely represented within Ireland as elderly survivors of the 1950s generation of working-class migrants. (It may be argued that positioning this cohort as economically disadvantaged provides an explanatory narrative for their 'oldfashioned' take on Irishness, as discussed above.) Funding is also provided for cultural groups - while this has been done on a largely ad hoc basis to date, there have been suggestions that the State should more systematically fund such initiatives in order to foster 'Irish mindedness and diasporic patriotism' (Ancien, Boyle, \& Kitchin, 2009, p. 9). Whether such initiatives will represent an engagement by the State with diasporic forms of Irishness, as opposed to a vision of the diaspora as a relatively homogeneous community of Irish abroad, remains to be seen. However, initiatives 
such as the 'certificate of Irish heritage' proposed by the current Irish Government as a means for those of Irish descent who are not eligible for citizenship to 'officially' proclaim their Irishness (Cullen, 2010) would appear to suggest that the Irish State has a monopoly on 'authentic' Irishness, which then becomes a saleable commodity. While such certificates may be aimed at members of the diaspora, they cannot be said to represent a diasporic Irishness, where this represents different deterritorialised forms of Irish identity that do not necessarily take their cues from the Irish nationstate.

This discourse of Irish 'authenticity' as a resource that is the preserve of the State but can be sold to members of the diaspora echoes the contemporary representation of the diaspora as a whole as, by and large, progressive, prosperous and potentially economically valuable to the Irish nation-state. For example, Hayward \& Howard (2006) have outlined the deliberate government strategy of encouraging 'cherrypicked' skilled workers among the Irish diaspora to relocate to Ireland, trading on emotive language of 'returning home', which was applied equally to those of Irish descent as those of Irish birth. Since the economic collapse of 2008, the Irish diaspora has increasingly been seen not just as a source of skilled workers but as a potential source of revenue and investment, surpassing the well-established emphasis on genealogical homecomings consistent in tourist promotions (Nash, 2008). For instance, the popular economist David McWilliams has argued that the diaspora can act as a resource that will serve as a form of 'soft power' to drive the Irish economy (McWilliams, 2009). Initiatives such as the Global Irish Economic Forum held at Farmleigh House ${ }^{1}$ in September 2009 for 'the most influential members of the global Irish community with a record of high achievement in business and culture, as well as 
a number of individuals with a strong business connection to Ireland' (Martin, 2009) were hailed by politicians, business leaders and media commentators alike as representing a new stage in Ireland's relationship with 'her' diaspora. What this new stage will constitute remains to be seen, but the picture so far would appear to suggest a formalised 'diaspora of the elites' driven largely by commercial and economic interests.

What both romanticised and economic discourses of the diaspora largely overlook are the material and psychological experiences of individual 'diasporans'. Discourses around the Irish diaspora within Ireland have yet to view it as a social phenomenon in its own right, and continue to conceptualise it as a prism through which contemporary Ireland can be viewed, or as a resource through which contemporary Ireland can be assisted. In particular, there is a tendency to gloss over the subjective experience of individual members of the diaspora and the level of agency they possess in articulating their own Irish identities (Gray, 2000).

The question therefore becomes whether the term 'diaspora' is adequate to reflect the variety of individual experiences and identity, or whether an alternative term such as 'transnationalism', would be more accurate (Mitchell, 1997). If the term 'diaspora' is retained, there is a need to articulate a more systematic research-based conceptualisation of Irish diaspora, and to integrate the experiences and identifications of individual members of the 'imagined community' of Irish worldwide, both contemporary and historical, with more theoretical perspectives on the nature of the Irish diaspora. Hickman (2002) articulates such an approach in calling for a hybrid, materialist concept of diaspora, which would combine 
perspectives from postmodern theorising of diaspora with empirical accounts of the socio-historical context of migration and settlement. Towards such an end, this paper examines how theories of diaspora and transnationalism are reflected at the individual level, by taking a discursive social psychological approach to the ways in which individual Irish people in England describe their own Irish identities and those of other people. From my own research among the Irish in England ${ }^{2}$, I argue that genuinely diasporic orientations are articulated by individual Irish people, but that these are constrained by a strong discourse of Irish authenticity through transnational knowledge.

\section{Diaspora and transnationalism - a worked distinction.}

It has been argued that the concept of transnationalism more accurately reflects the material patterns of individual 'national' lives outside the nation than diaspora. The term 'transnationalism' was originally conceived at least partly as a reaction to the overly abstracted, dematerialised nature of much of the theorisation of diaspora, as well as a means of accounting for the ways in which new technology and transport have made new forms of multiply-located lives possible (Portes, Guarnizo, \& Landolt, 1999; Vertovec, 1999). However, this original distinction between 'transnationalism' and 'diaspora' has been elided to the extent that the two terms have become almost interchangeable. The lack of consensus as to how the two terms relate to each other, has been explored by Brettell (2006). She outlines how some authors suggest that transnational communities are the 'building blocks' of diaspora, whereas others argue that transnationalism is supplanting diaspora as the relevant concept, or that transnationalism represents a dual allegiance to host and origin countries, whereas 
diaspora represents a wider spread of allegiances: a 'diaspora consciousness', so to speak.

It is the latter distinction that will be adopted for the purposes of this paper, although I wish to interrogate the notion of dual allegiances further. Rather than diasporic or transnational lenses representing alternative explanatory frameworks through which the Irish abroad can be explained, I argue that the two co-exist as a series of perspectives, identifications and allegiances within which national lives outside the nation can be situated. Re-iterating the social psychological focus of this paper on the individual subject, 'transnationalism' here represents the extent to which a life is lived in two (or more) countries simultaneously, whether that be materially, socially, economically or affectively. 'Diaspora' meanwhile, taken in its applied, rather than its theoretical sense, here represents the extent to which a 'national' life is lived outside the nation, without necessarily reproducing the set of meaning-makings around the national that are promoted by the nation-state.

This definition of transnationalism does not imply dual allegiances as this implicitly assumes an equal relationship in terms of power between the two national spheres. It is pertinent here to take the example of the transnational migrant that belongs to a majority population in one national sphere and a minority population in another, as is the case for many Irish transnational migrants. It could be hypothesised that individuals who lead transnational lives will tend to orientate to those sets of meanings around national identity that correspond with the nation state in which they are a member of the majority population. Such individuals become the embodiment of a transplanted national identity that closely resembles that which resides in the 
nation-state. Where this comes in contact with more diasporic imaginings of identity (e.g. long-term or second generation Irish residents in England), this is likely to create contestation around authenticity. In order to investigate how such contestations may be shaped, it is necessary to give some historical and geographical context on the Irish in England.

\section{The Irish in England - historical and geographical context}

As outlined by authors such as O’Connor (1972), Akenson (1993), Davis (2000) and MacRaild (1999), migration in both directions between Ireland and England has been a more or less constant phenomenon for centuries, due to the proximity of the two countries. While these historical migrations have undoubtedly influenced how Irishness continues to be perceived in England, the current position of the Irish in England has been largely shaped by the two peak, post-war periods of Irish migration to England in the 1950s and the 1980s, which coincided with major periods of recession in the Irish economy. Geographically, while London has always been a significant destination of choice for Irish migrants, large numbers of the 1950s generation of migrants found employment and settled in the West Midlands and in towns associated with manufacturing and construction. This was not true of later migration, which was largely, although by no means exclusively, directed towards London and the South-East (MacLaughlin, 1997; Walter, 2008a). Irishness outside these areas is now largely becoming a second generation phenomenon, given the age profile and dwindling numbers of the original 1950s migrants. 
In considering Irish identities in England, it has been much remarked upon that there is no 'national' equivalent to the high-profile hyphenated Irish-American identity that is relatively readily available to members of the diaspora living in the United States (Hickman, 2002). This is largely attributable to the legacy of colonialism between the two countries and the fact that 'official' Irish identities have historically been defined in opposition to British and, particularly, English ones (Tovey \& Share, 2003). Similarly, but somewhat less remarked upon, racialised typographies of the 'superior' Anglo-Saxon were largely built upon comparisons to the 'inferior' Celt, particularly the Irish (Curtis, 1984; Douglas, 2002). At the same time, it has on various occasions been politically expedient for successive British governments to deny any major cultural differences between Irish immigrants and the 'native' population, particularly with regard to whether the Irish should be regarded as an ethnic minority. This forced inclusion within a 'myth of cultural homogeneity' (Hickman, 2000), while at the same time being regarded as 'Other', complicated the articulation of Irish identities and consigned the concerns of the Irish as a minority group, to invisibility.

The advent of the IRA bombing campaign in English cities in the 1970s and 1980s exacerbated the difficulty of articulating a positive Irish identity within England; the Irish during this time entered a phase of being regarded as a 'suspect community' (Hillyard, 1993). More positively, since the 1990s, there has been a remarkable turnaround in the perception of Irishness in England, attributable to the Northern Ireland peace process, the increasing popularity of certain, often highly commercialised, aspects of Irish culture, a growing tendency to frame Irishness within a multicultural paradigm and, importantly, decades of activism from Irish community groups (Mac an Ghaill, 2000, 2001; Nagle, 2008). There has also been a growing 
recognition of Irishness as an ethnicity within a multicultural context, resulting in 'White (Irish)' being included for the first time as an ethnic category in the 2001 England \& Wales census. However, the legacy of the preceding decades of antagonism, colonialism and distrust still informs the lack of conceptual space for claiming a hyphenated English-Irish identity. This perceived incompatibility of Irishness and Englishness is problematic for those of Irish descent in England, who may identify with Irishness, but have their Irish identities questioned due to their English birthplace and accents (Hickman, Morgan, Walter, \& Bradley, 2005; Walter, 2008b).

Returning to the question of diasporic and transnational imagining of Irishness in England, therefore, Delaney (2005) has pointed out that the Irish in England have to some extent always been characterised by transnationalism, given the proximity of the two countries and the existence of kinship and localised networks that spanned the two countries in facilitating migration and continued contact between the two. It is the very strength of these transnational ties that make the expression of a diasporic, in the sense of an alternative to a territorialised, Irish identity in England so fascinating and complex. Irishness in England is constantly re-inscribed by Irishness in Ireland to a greater extent than other sites of Irishness abroad, which simultaneously informs and constrains the ways in which an 'authentic' diasporic Irish identity can be articulated. Given the earlier distinction between the ways in which diaspora and transnationalism operate, it is among the Irish diaspora in England that a constant dialectic between the two is seen - diasporic in that imaginings of Irishness go beyond those of the nationstate, and are influenced by the material, structural differences of living in England, 
and yet transnational in that articulations of such imaginings are constantly challenged due to proximity to the 'homeland' and the constant arrival of 'new' Irish migrants.

\section{Empirical perspectives on the Irish in England.}

Past empirical research on the Irish in England reveal such encounters between alternative imaginings of Irishness. For example, Breda Gray's research (Gray, 1996a, 1996b, 1999, 2000, 2004) illustrated a generation gap in concepts of authentic Irish identity between the cohort who migrated in the 1950s, and that which migrated in the 1980s. Gray's participants define themselves against what they see as the 'cringingly' excessive Irishness of the older migrants, in favour of more individualistic assertions of Irish identity. For example, one of her participants rejects the notion of being positioned as an 'Irish woman' due to its association with attending Irish clubs and functions, whereas another justifies labelling the cultural forms associated with performances of Irishness in England as inauthentic, as 'we never did this at home' (Gray, 2004, pp. 109-110).

It has been argued e.g. (Campbell, 1999; Mac an Ghaill \& Haywood, 2003) that these middle-class Irish migrants of the 1980s represented and positioned themselves as an 'economic emigrant aristocracy', simultaneously distinct from 'traditional' forms of Irishness within England and embodying a type of national authenticity with regard to 'modern Ireland'. The parallel with emerging State discourses of the Irish diaspora discussed earlier is striking, and it may be argued that more recent migrants therefore embody the modern transnational state, to an extent that older migrants and those of Irish descent do not. Therefore, I would argue that such distancing from forms of 
Irishness that have evolved in England relatively independently of the changing meanings of Irishness in Ireland represents a prioritising of territorialised understandings of Irishness, and as such draws on transnational rather than diasporic discourses of Irish authenticity.

Given this distancing work, it is tempting to cast the 'middle-class' 1980s generation and those who migrated subsequently in the 1990s and 2000s as the protagonists with regard to positioning the Irish identities of other people in England as inauthentic. However, rather than simply portraying this as a clash of different demographic cohorts, I conceptualise it as a dialectic between two distinct discourses of Irish authenticity: authenticity through transnational knowledge and authenticity through diasporic claim. ${ }^{3}$ Speaking in terms of discourses, rather than demographics, allows a deeper level of analysis of the various claims on national identity by individual Irish people in England, than assuming uniform viewpoints within cohorts of Irish migrants. This is not to say that discourses of authenticity and national identity are not influenced by, or closely associated with, issues of class, age cohort, gender, geographical origin, religious affiliation and observance etc., but rather that these associations are more fluid and less concrete than might be imagined. Consequently, while I provide relevant demographic detail for each of the participants quoted in this article, it should not be assumed that they have been selected as representative of 'their' cohort. Rather, this detail is provided to give additional insight on how the participants position themselves and others within discourses of Irish authenticity in England. 
It may be seen from this that having the rhetorical cachet to position oneself as youthful, modern, and in touch with contemporary Ireland, allows one to differentiate between 'modern' and 'outdated' forms of Irishness through discourses of transnational knowledge. For example, the following extract comes from my discussion with Liam ${ }^{4}$, a professional Irish migrant in his 20s living in London:

Liam: A lot of the guys that came over here, who now have kids my age over here, came over here because they had no choice, so they came over to work. So, a lot of them have made a lot of money, but education-wise it wouldn't have been the same as it is for somebody who's emigrating now; even the basic immigration; some guy comes over into construction now has more than likely done his Leaving Cert, at least, which means he's done a reasonable standard of education, right, so, a guy who left forty years ago, left when he was sixteen when he had very little education and it wouldn't have been the same standard of education as it is now, he would have had no interest in education when he came over here; he came over here to make money to work, to send money home and he met an Irish girl and they lived, set up a life up in Cricklewood ${ }^{5}$, drank in the bars, played football, went home, went to the Galtymore ${ }^{6}$ every Friday, went home twice a year, and had no clue what was going on in Ireland, weren't really aware of the Celtic Tiger or what it actually meant; they read about it but they didn't really know what it meant, and they never really progressed as quickly as we do; not all of them, but some of them, definitely, it's still the case. You meet fellas here, they've the thickest Irish accent, you'd swear they were only just over and they're here fifty years, d'you know? I mean I imagine if I lived in New York for fifty years that I'd eventually get an American accent and at least find myself being American you know, in some ways. Obviously you'd always say you're Irish but I mean these guys just won't let go of anything. 
Liam's portrayal of the forms of Irishness associated with older Irish people in London is a largely negative one. He positions them as being poorly educated and unwilling or unable to integrate or to 'let go' of their outmoded form of Irishness, as defined in relation to Irishness in Ireland. Here, paradoxically, it is the very participation of the Irish in London in Irish events and activities that marks them as 'inauthentic', due to its association with a form of Irishness that has not 'progressed as quickly' as Irishness in Ireland. It is Irishness in Ireland that is held up as the standard of Irish authenticity and therefore knowledge of events and recent developments in Ireland that allows claims to be made on an authentic Irish identity. To lack understanding of such events e.g. not to know what the Celtic Tiger really means, is to be positioned as inauthentic.

As mentioned earlier, past research has also emphasised the ways in which more recent migrants distanced themselves from those of Irish descent - largely through an emphasis on birthplace and accent as essential markers of Irish identity, and through the use of the term 'Plastic Paddy' to mark as inauthentic those who were seen as making illegitimate claims on Irishness (Hickman, 2002; Hickman et al., 2005; Mac an Ghaill \& Haywood, 2003; Walter, 2004, 2008b). Likewise the fear of being labelled a 'Plastic Paddy' is referred to by the second generation as a reason for not 'overstretching' in claiming an unproblematic fully authentic Irish identity (Walter, 2004). As such, the use of this pejorative term can be seen as a transnational constraint on diasporic expressions of Irishness. 
However, it ought to be noted that the use of the term 'Plastic Paddy' in second generation discourse is far from universal. ${ }^{7}$ Rather than the term providing a constraint on the articulation of authentic second generation Irish identities, others have challenged the term as a means of deconstructing singular territorially-bound versions of Irishness, as noted by Campbell (1999). A similar example of such challenging is provided from my interview with Kate, a second-generation Irish woman in her forties:

Kate: I don't like that term Plastic Paddy because it's not like you're a fake, 'cause that's the- to me that the image is it's a fake paddy, I don't consider myself a fake Irish person, I'm just different you know, there's a spectrum of Irish and I'm on it somewhere

Kate illustrates that, for her, the use of the term 'Plastic Paddy' is a means of positioning her as 'fake'. In order to speak against this positioning, Kate constructs Irishness as a spectrum, on which she can be located, rather than a static entity, or something that is territorially bound in Ireland. Thus, the rhetorical answer to being labelled 'fake' is to make a claim of 'not fake, just different'. This kind of articulation may be represented as an individual member of the Irish diaspora arguing for a less hegemonic, more multi-faceted and diasporic reading of Irishness as against a transnational reading of Irishness in England that prioritises similarity to Irishness in Ireland as 'authentic'. However, the very fact that this diasporic claim needs to be made would suggest that this is not the dominant understanding of Irishness in England. 
It has been established that one of the means by which second-generation Irish people articulate the specificity of their diasporic Irish identities in England has been through the adoption of hybridised city-based Irish identities, such as 'London-Irish', ‘Birmingham-Irish', 'Liverpool-Irish’ etc. (Hickman et al., 2005; Walter, 2001). Such hyphenated identities may be seen as simultaneously an expression of a shared citybased Irish upbringing and experience and a rhetorical means of defence against being labelled 'inauthentic'. As such they may be situated in a discourse of authenticity through diasporic claim, while recognising the potency of the discourse of Irish authenticity through transnational knowledge. As an example of the former, the extract below also comes from my interview with Kate, who earlier in the interview had briefly mentioned her involvement in the London-Irish music scene of the early 1980s, spearheaded by the Pogues. Campbell (1999) has written of the significance 'of the Pogues' post-punk reconfiguration of Irish 'folk' music, which articulated a peculiarly Diasporic (London) Irish experience at a time when it was neither popular nor fashionable to be Irish in Britain' (p.275), something of particular relevance to the second generation. On my questioning as to her involvement in this scene, she recounted a number of occasions on which her own band had shared a bill with the Pogues:

Kate: there's a couple of famous nights we did in the Irish Centre in Camden which we did as fundraisers for the Irish Centre so I know The Pogues did a photo shoot for their first album in there with a big portrait Kennedy-John F Kennedy, yeah that was in the Irish Centre in Camden. So yeah so that was that whole scene and that was very much about saying we're Irish but we're not paddies, we're London-Irish and it was a very different identity to being first generation 
The London-Irish music scene is constructed by Kate as being deliberately about articulating a type of Irishness that is situated in London and is explicitly differentiated from the 'Paddies', the first generation migrants. This then, is a very specific form of positioning - one that seeks to claim Irishness, but disassociate itself from the possible negative connotations associated with being a 'Paddy'. Physically, the narrative is situated within the Irish Centre in Camden, an iconic site of Irishness in London, and Kate invokes the image of the Pogues being photographed around the portrait of John F Kennedy (another icon of diasporic Irishness) within the centre. Thus, the image is of the London-Irish claiming a diasporic Irish authenticity without necessarily referring to Ireland.

On the other hand, Sinéad, a second-generation Irish woman in London of a similar age to Kate articulated a more defensive form of London-Irishness. The extract below follows a stage in the interview when I had asked her at what point she had started to adopt a London-Irish identity:

Sinéad: I think my first memory was actually being at a party probably I was about nineteen or twenty, eighteen, nineteen or twenty and I remember some girls-the first time somebody said to me, I think it was probably those silly things you're at a party and they were actually born in Ireland working over here and we were at a party, a mutual friends party, a guys party, I don't know whether they felt-saw me and my friend as a bit of threat or whatever but that was the first time somebody said to me 'yeah but you're just a Plastic Paddy anyway' and I said 'yeah I'm what?' Interviewer: Had you heard the term before or?

Sinéad: I had heard the term but nobody had said it to me it was the first time that somebody said it to me and it made me- 
Interviewer: And it was said like in a denigratory way like it wasn't done in joke

Sinéad: It was yeah, I mean I have had other people tease me about it since then and I've probably been older so I wouldn't react in the same way but no that person used it as ammunition and it riled me it really did

The fact that Sinéad answers my query about the timescale around which she had started to adopt a London-Irish identity with an anecdote about the first time she, personally, had been referred to as a 'Plastic Paddy' is indicative of the means by which London-Irishness is positioned as a defensive identity. I later attempted to develop this point, by suggesting that London in the 1980s may have been a site of contestation between two quite different versions of Irishness and that the emergence of London-Irishness may have been a way of differentiating Irish experience in London from Irish-born migrants (as with Kate above):

Sinéad: I would say we wouldn't have wanted to differentiate but they quite clearly, I feel they wanted to differentiate from us, we didn't, we wanted to be part of it all, be the same of it, but it was them coming over who didn't. Well I can only talk for my own perspective of course, that's how I perceived the situation and somebody come over from Ireland my age would probably tell you something very different, but I felt the differentiation was on their side not on ours that we didn't want-that we wanted to be associated and of course it was only a minority who made you feel like that the majority didn't so

Interviewer: I mean now you would describe yourself as London-Irish

Sinéad: I think I would because I never want-I don't think I ever wanted to differentiate myself as London-Irish but a few things that were said and done, a few things that have happened to London-Irish people, it makes you feel 'okay well we 
need to fight-maybe fight your corner a bit more' so I don't think I ever wanted to be a London-Irish person but somehow it's evolved maybe from my personal experiences

Sinéad emphasises that it was 'them', the new young migrants, who wanted to differentiate from 'us', the second generation who 'wanted to be part of it all'. Adopting a London-Irish identity is constructed by Sinéad not as a choice she was able to make freely, but rather as something that emerged in a defensive context, having had the means by which she could articulate her personal Irishness constrained by the new arrivals. As such, there is less of a sense of actively constructing a new, exciting hybrid identity in Sinéad's narrative, as there is in Kate's. Rather, by emphasising her claim that she never wanted to be London-Irish, she suggests that it is an identity that she has felt obliged to adopt out of solidarity with other LondonIrish people, and as a defence against being labelled a 'Plastic Paddy'. Sinéad's diasporic claim on authentic Irishness is therefore constructed as a reaction to the more exclusionary aspects of transnational discourses of Irish authenticity.

Such patterns regarding the adoption of hyphenated local-national identities as a reaction to the estranging nature of transnational discourses of authenticity are not confined to Irishness in London. For example, the following extract is taken from a group discussion with three second-generation Irish colleagues in Birmingham. Within this discussion, Sarah is in her twenties, Becky in her thirties, and Eileen in her fifties:

Sarah: I just think there is that fear of the 'Plastic Paddy', by being called a 'Plastic Paddy'; it, well, it doesn't really bother me but I know that it, some people 
really hate it because its hard to, like; they can have a complete Irish upbringing and be considered maybe Irish by people over here, but if they're in Ireland it's just that they're like; I suppose they could call themselves, they'd call themselves maybe 'Birmingham-Irish', but they wouldn't call themselves 'Irish-Irish'

Eileen: I think that's quite a

Becky: It's a fear of being criticised more

Eileen: Yeah, well I think so. Generally people don't like to be different; you know, generally people like to fit in.

The women in the group describe a process by which second generation Irish people in Birmingham come to describe themselves as Birmingham-Irish as a means of avoiding being labelled a 'Plastic Paddy'. Adopting a hybridised label is a means of creating conceptual space for a diasporic Irishness to be imagined, one that emphasises the localised, Birmingham-based specificity of their Irish identities. However, the adoption of these labels only reflects a limited amount of agency in claiming Irishness - the extract makes it clear that the constraints placed on second generation identity by the existence of the 'Plastic Paddy' trope mean that people feel unable to claim an unqualified Irishness, reflecting the discursive power of the label. The possibility of being labelled a 'Plastic Paddy' is constructed in this extract as something that cannot simply be ignored or rejected, but rather accommodated, by pre-emptively adopting a qualified Irish identity.

An interesting aspect of this extract is that Sarah refers to the difficulty experienced by second-generation people of articulating their own sense of Irishness within Ireland. This illustrates that transnational lives are not confined to recent Irish-born migrants, and that second-generation Irish people may also draw on their own 
experiences in and knowledge of contemporary Ireland in constructing their own Irish identities. While this may be expressed in terms of the estranging effects of being positioned as not 'properly' Irish in Ireland (e.g. while visiting family) it may also open up the possibility that the discourse of transnational knowledge becomes available to second-generation Irish people when carrying out rhetorical work regarding their own Irish identities. For example, the following extract is taken from my interview with Becky, who is here recounting the tensions caused by the question of who gets to represent Irishness in Birmingham at meetings of the Irish community group she works for:

Becky: We'd have a meeting, one of our AGMs for instance, and you've got three people sitting on the top table and none of them were born in Ireland, they all have Irish heritage. The people in the crowd, bitter and twisted some of them, will be at, but they would use that as a weapon to sort of argue the toss of something like "what would know what we want; you're not even Irish" or "you weren't born in Ireland; how do you know what, how Ireland can be reflected within the Irish Quarter" say. It's that these people that lived in Ireland probably hadn't been back for like forty years, whereas the people sitting on the top table are regular visitors and go back and see family and are active within the community, in the hobbies, in the culture. It's the older generation who think that they have the monopoly on being Irish and that the Birmingham Irish, or the youth or the second generation however you want to say it here, don't really have the right to tell them what they would like to see for example, in an Irish quarter

Interviewer: Right, so it's kind of different versions of Irishness competing

Becky: That's it, yeah. And I think that the people that are born in Birmingham of Irish heritage can see the contemporary side; contemporary's the wrong word; they can see how traditional Ireland, picking a piece up and putting it here, into the heart 
of the Irish Quarter wouldn't work, cause it has to mix with today, so the modern day and also a bit of Birmingham in there you know, it's the kind of BirminghamIrish theme.

Interestingly, this extract reflects a clash between two different takes on the transnational discourse. Becky describes the way in which older Irish migrants would use the fact of the non-Irish birth of the 'people sitting on the top table' as 'a weapon' in arguments about Irishness (this may be compared to Sinéad's account of the 'Plastic Paddy' term being used as 'ammunition'). Becky rhetorically counters this argument in two ways: firstly, by representing it as an illegitimate criticism of those 'at the top table' by constructing heritage and community involvement as being more important and relevant to an Irishness that is situated in Birmingham. In this respect her comparison between those who 'think they have the monopoly on being Irish' and those who can articulate 'the Birmingham-Irish theme' is illuminating: the latter, which is constructed as the more relevant identity is a specifically hybridised and diasporic one: taking its cues from the urban surroundings in Birmingham rather than 'traditional Ireland'.

Secondly, Becky also employs the discourse of authenticity through transnational knowledge to turn the argument around. Those at the top table are constructed as visiting Ireland more regularly than the 'bitter and twisted' people in the crowd who 'probably haven't been back for forty years'. The second generation Irish are therefore positioned as more in touch with contemporary Ireland than the older generation who are positioned as having an unrealistic view of both Ireland, and how a diasporic Irishness can be represented in Birmingham. Thus, the 'contemporary and 
modern' is set against the 'traditional and old-fashioned', much as it was in Liam's earlier account.

Therefore, while discourses of Irishness as transnational or diasporic may be largely associated with certain cohorts of Irish people, they are not exclusively so. Nor is it inevitable that such understandings of Irishness will be arranged in opposition to one another - they are both available as resources that may be employed, depending on the identity work that is being done in the immediate context. The fluidity of these discourses and that both may be drawn upon in a conversation is illustrated by the following extract, where Éamonn, an Irish migrant in his early thirties living in London discusses second generation people he knows:

Éamonn: I found out if you accidentally referred to them as the English lads would get very upset about it, they really would you know, "I'm not fucking English like" or you know, I mean for some of them they didn't make any differentiation, they said "I'm Irish" and that's it, none of this, they didn't qualify it with London-Irish or second generation, just "I'm Irish" and I could see why they thought that because the circles that they moved in, it wasn't even so much the Irish community here, it was the London-Irish community here, and that meant the same thing as being born in Ireland and moving to London, you know. I think this London-Irish tag, which I'm sure you could probably write a thesis on in and of itself is a funnit's kind of, you know, you got the guys who were born here and then you've got guys who've maybe lived here for so long and have absolutely no intention of going back that they've become London-Irish as well, and it's just Irishness which has developed itself in a foreign clime, it's a very different thing, you know, and I'm still sort of, I don't know, I mean, their world sort of surrounds the various Irish districts in London, you know, it doesn't look back to home so much. So when I 
was talking to these London-Irish lads, you know, they all knew their hurling and they all knew, you know they were asking me about w- of the three clubs, they all knew that there was three hurling clubs in Down, the senior clubs and they all knew their stuff but if you were talking about any sort of, if you getting too much about you talking about, you know, modern Ireland or whatever, they wouldn't make that connection so much, you know, they wouldn't, you wouldn't be there talking about 'oh did you hear' you know I don't know 'hear about the Late Late Show the other week' or something like that, they wouldn't, that wouldn't register with them so much so they, you know, they're like you, but they're not. But they're more like us than anybody else I can think of over here, you know.

Éamonn stresses the difference between the 'foreign' Irishness that has developed around the various Irish districts in London and the contemporary Irishness of 'modern Ireland'. In doing this, he highlights the uneven level of knowledge the second generation Irish people of his acquaintance have of modern Ireland, portraying them as having an extensive knowledge of certain aspects, mostly to do with sport, but little or no knowledge of other aspects of popular culture and current affairs within Ireland. Thus, Éamonn draws on a discourse of Irish authenticity through transnational knowledge as a way of differentiating between 'us', the migrants, and 'them', the London-Irish, in whose number he also includes long-term migrants who 'have absolutely no intention of going back'. However, while he positions the London-Irish as embodying a different kind of Irishness to 'us', he doesn't portray this Irishness as inauthentic to the same extent as is done elsewhere. Rather, in recognising the specific form of Irishness embodied by the London-Irish and in positioning them as 'like you, but not, but more like us than anybody else I can think of over here', it could be argued that there is a certain recognition that the second 
generation occupy a liminal space between the Irish-born and the 'foreign', and that there is potential for this space to be defined on their own terms. In other words, while Éamonn situates his personal understanding of Irishness within a transnational discourse, he also recognises the existence of diasporic versions of Irishness as a separate phenomenon, as opposed to an 'incorrect' take on Irishness. Therefore, while there is still evidence that younger migrants may differentiate themselves from other Irish groups in England, differentiation does not automatically imply derogation.

Placing a greater emphasis on the fluidity of use of discourses of Irish authenticity in England does not amount to a decoupling of such discourses from uneven power relations between various cohorts of Irish in England. As noted by Mac an Ghaill and Haywood (2003), and reflected in Liam's description of the elderly Irish in London, class and education-based discourses do permeate the positioning of certain Irishnesses as inauthentic, while largely simultaneously reaffirming the authenticity of the Irish identities of younger, more middle-class migrants with transnational orientations. However, to depict Irishness in England merely as contested between various demographic cohorts is to give an incomplete picture. As I have demonstrated, the fluidity of identification with Irishness in England is more accurately described in terms of contrasting discourses rooted in understandings of Irishness as transnational and Irishness as diasporic. While these discourses may be, and regularly are rhetorically arranged in opposition to each other, they have the potential to be employed in various ways in conversation by a range of Irish people in England, as opposed to one specific demographic cohort. However, having said this, this does not imply that each understanding of Irishness has an equal discursive power. While the use of discourses is context-dependent, it remains the case that 
discourses of Irish authenticity through diasporic claim are drawn upon when accounting for identities that are positioned as inauthentic by transnational understandings of Irishness, rather than vice versa. In other words, it would appear that the transnational discourse of Irishness remains the standard through which articulations of alternative Irishnesses are understood.

\section{Conclusion}

The data explored in this paper goes some way towards illuminating the identities and allegiances of individual members of the Irish diaspora in England, and so correcting the ongoing tendency within Ireland to conceptualise the diaspora as homogenous and as an extension of the Irish nation-state. As can be seen from the research presented above, questions of 'authenticity' permeate the diaspora, and one of the major rhetorical arguments used to separate the 'authentic' from the 'inauthentic', is an allegiance to and knowledge of contemporary Ireland.

This creates certain issues with regard to the ways in which the Irish State engages with the Irish diaspora. While state actors may wish to foster an image of a progressive, modern nation, and the Irish abroad as embodied exemplars of this national image through a diaspora strategy, an unwillingness to engage with the various, sometimes contradictory ways in which Irishness is imagined and identified with throughout the lived diaspora may ultimately prove counter-productive. Where the diaspora are conceptualised as an economic resource that can be prevailed upon to assist the Irish nation-state in its time of need, this would appear to envisage a 
diaspora that is assumed to take contemporary Ireland as its primary reference-point with regard Irishness: in other words, this view assumes transnational orientations. A diaspora strategy, which in taking a narrow economic view of what diaspora constitutes, seeks to promote 'authentic' Irishness as a commodity residing within the nation-state runs the risk of alienating those with more diasporic orientations.

The distinctions between diaspora and transnationalism that I have employed in this paper have been useful in exploring how such terms operate in a material, as opposed to an overly abstract theorised way. Given the unique historical and geographical factors that have shaped Irishness in England, I do not claim that this distinction necessarily holds for other groups that may be described as diasporic or transnational (or both). However, it may provide a way of thinking about diaspora and transnationalism at the level of individual identity and practice that may prove useful in similar future studies.

(9,443 words)

\section{Notes}

\footnotetext{
${ }^{1}$ The official Irish State Guest House.

2 This paper is based on my $\mathrm{PhD}$ research which examined national identity and discourses of authenticity among the Irish in England. The data extracts are taken from interviews and discussion groups I carried out with a variety of people of both Irish birth and descent in England over the course of 2008. Recruitment in this case was determined solely by identification as Irish, and therefore participants from both the Republic of Ireland and Northern Ireland were interviewed, with the majority of participants identifying with localities within the Republic. All participants either selfidentified as Roman Catholic, or did not explicitly state their religion. The main sites of the research were London, Birmingham and Milton Keynes.
} 


\footnotetext{
${ }^{3} \mathrm{My} \mathrm{PhD}$ research also identified a third discourse of Irish authenticity in England: that of "authenticity through collective experience and memory". See Scully (2010).

${ }_{5}^{4}$ All names of participants have been anonymised.

${ }_{6}^{5} \mathrm{An}$ area of London with a large Irish migrant population.

${ }^{6}$ A large and somewhat iconic Irish dancehall in Cricklewood. Closed in early 2008.

${ }^{7}$ For a fuller exploration of the various ways in which the second-generation participants in my research accounted for the term 'Plastic Paddy' in articulating their own Irish identities, see Scully (2009).
} 


\section{References}

Akenson, D. H. (1993) The Irish diaspora : a primer. Toronto: P.D. Meany ; Belfast : Institute of Irish Studies, The Queen's University of Belfast.

Ancien, D., Boyle, M., \& Kitchin, R. (2009). Exploring Diaspora Strategies: Lessons for Ireland. Maynooth: National Institute for Regional and Spatial Analysis, NUI Maynooth.

Bhabha, H. K. (1990) Nation and narration. London: Routledge.

Bhabha, H. K. (1994) The location of culture: Critical theory and the postcolonial perspective. London: Routledge.

Bishop, P. (1999) The Irish empire. London: Boxtree.

Bowden, N. (2010, 3rd October 2010). Is "emigration" taboo? globalirish.ie: about emigration and diaspora Retrieved 27th October 2010, from http://www.globalirish.ie/2010/is-emigration-taboo/

Brah, A. (1996) Cartographies of diaspora : contesting identities. London: Routledge.

Brettell, C. B. (2006) Introduction: Global Spaces/Local Places: Transnationalism, Diaspora, and the Meaning of Home. Identities, 13, 327-334.

Brubaker, R. (2005) The 'diaspora' diaspora. Ethnic and Racial Studies, 28, 1-19.

Campbell, S. (1999) Beyond 'Plastic Paddy': A Re-examination of the SecondGeneration Irish in England. Immigrants and Minorities, 18(2/3), 266-288.

Clifford, J. (1994) Diasporas. Cultural Anthropology, 9(3), 302.

Coogan, T. P. (2000) Wherever green is worn : the story of the Irish diaspora. London: Hutchinson.

Cullen, P. (1999) Identity, emigration and the boomerang generation. Paper presented at Emerging Irish Identities, Trinity College Dublin, 27th November 1999, 7576.

Cullen, P. (2010) Certificate of Irishness open to 70 million people worldwide. The Irish Times, 21st June 2010 from http://www.irishtimes.com/newspaper/frontpage/2010/0621/1224272953828.h $\underline{\mathrm{tml}}$.

Curtis, L. (1984) Nothing but the same old story : the roots of anti-Irish racism. London: Information on Ireland.

Davis, G. (2000). The Irish in Britain, 1815-1939. In A. Bielenberg (Ed.), The Irish Diaspora (pp. 19-36). Harlow: Pearson Education.

Delaney, E. (2005) Transnationalism, Networks and Emigration from Post-War Ireland. Immigrants and Minorities, 23, 425-445.

Douglas, R. M. (2002) Anglo-Saxons and Attacotti: the racialization of Irishness in Britain between the World Wars. Ethnic and Racial Studies, 25(1), 40-63.

Gilroy, P. (1997). Diaspora and the Detours of Identity. In K. Woodward (Ed.), Identity and Difference. London: Sage.

Gray, B. (1996a) Accounts of Displacement Irish migrant women in London. Youth and Policy, 52, 22-29.

Gray, B. (1996b) Irish Women in London: National or Hybrid Diasporic Identities? National Women's Studies Association Journal, 8(1), 85-109.

Gray, B. (1999) Longings and Belongings - Gendered Spatialities of Irishness. Irish Studies Review, 7(2), 193-210. 
Gray, B. (2000) Gendering the Irish Diaspora: Questions of Enrichment, Hybridization and Return. Womens Studies International Forum, 23(2), 167185.

Gray, B. (2002) The Irish Diaspora: Globalised Belonging(S). Irish Journal of Sociology, 11, 123-144.

Gray, B. (2004) Women and the Irish diaspora (1st ed.). London ; New York: Routledge.

Hayward, K., \& Howard, K. (2006). Cherry-picking the diaspora. In B. Fanning (Ed.), Immigration and Social Change in the Republic of Ireland (pp. 47-62). Manchester: Manchester University Press.

Hickman, M. J. (2000) 'Binary Opposites' or 'Unique Neighbours'? The Irish in Multi-ethnic Britain. Political Quarterly, 71(1), 50-58.

Hickman, M. J. (2002) 'Locating' the Irish Diaspora. Irish Journal of Sociology, 11, 8-26.

Hickman, M. J., Morgan, S., Walter, B., \& Bradley, J. (2005) The Limitations of Whiteness and the Boundaries of Englishness. Ethnicities, 5, 160-182.

Hillyard, P. (1993) Suspect community : people's experience of the Prevention of Terrorism Acts in Britain. London: Pluto Press in association with Liberty.

Mac an Ghaill, M. (2000) The Irish in Britain: the invisibility of ethnicity and antiIrish racism. Journal of Ethnic and Migration Studies, 26(1), 137-147.

Mac an Ghaill, M. (2001) British Critical Theorists: The Production of the Conceptual Invisibility of the Irish Diaspora. Social Identities, 7(2), 179-202.

Mac an Ghaill, M., \& Haywood, C. (2003) Young (male) Irelanders: postcolonial ethnicities - expanding the nation and Irishness. European Journal of Cultural Studies, 6, 386-403.

Mac Éinrí, P., \& Lambkin, B. (2002) Whose Diaspora? Whose migration? Whose identity? Some current issues in Irish migration studies. Irish Journal of Psychology, 23(3), 127-157.

MacLaughlin, J. (1997). The New Vanishing Irish: Social Characteristics of 'new Wave' Irish Emigration. In J. MacLaughlin (Ed.), Location and Dislocation in contemporary Irish society (pp. 133-157). Cork: Cork University Press.

MacRaild, D. M. (1999) Irish migrants in modern Britain, 1750-1922. Basingstoke: Macmillan.

Martin, M. (2009). Minister's Welcome - The Global Irish Economic Forum. Retrieved 7th April 2010, from http://www.globalirishforum.ie/2009Forum.aspx

McWilliams, D. (2009) Diaspora can foster future success. The Sunday Business Post, 30th August.

Mitchell, K. (1997) Different diasporas and the hype of hybridity. Environment and Planning D, 15(5), 533-554.

Nagle, J. (2008) Multiculturalism's double bind: Creating inclusivity, difference and cross-community alliances with the London-Irish. Ethnicities, 8(2), 177-198.

Nash, C. (2008) Of Irish descent : origin stories, genealogy, and the politics of belonging (1st ed. ed.). Syracuse, N.Y.: Syracuse University Press.

O'Connor, K. (1972) The Irish in Britain. London: Sidgwick \& Jackson.

Portes, A., Guarnizo, L. E., \& Landolt, P. (1999) The study of transnationalism: Pitfalls and promise of an emergent research field. Ethnic and Racial Studies, 22(2), 217-237. 
Scully, M. (2009) 'Plastic and Proud'? Discourses of Authenticity among the SecondGeneration Irish in England. Psychology \& Society, 2(2), 124-135.

Scully, M. (2010) Discourses of authenticity and national identity among the Irish diaspora in England. The Open University, Milton Keynes.

Tovey, H., \& Share, P. (2003) A sociology of Ireland (2nd ed.). Dublin: Gill \& Macmillan.

Vertovec, S. (1999) Conceiving and researching transnationalism. Ethnic and Racial Studies, 22(2), 447-462.

Walter, B. (2001) Outsiders inside : whiteness, place and Irish women. London: Routledge.

Walter, B. (2004) Irish women in the diaspora: Exclusions and inclusions. Womens Studies International Forum, 27(4), 369-384.

Walter, B. (2008a) From 'flood' to 'trickle': Irish migration to Britain 1987-2006. Irish Geography, 41, 181-194.

Walter, B. (2008b). Voices in other ears: "accents" and identities of the first- and second-generation Irish in England. In G. Rings \& A. Ife (Eds.), Neo-colonial mentalities in contemporary Europe?: Language and discourse in the construction of identities (pp. 174-182). Cambridge: Cambridge Scholars Publishing.

\section{Biographical details:}

Marc Scully completed his $\mathrm{PhD}$ entitled "Discourses of authenticity and national identity among the Irish diaspora in England" in 2010 at the Department of Psychology at the Open University under the supervision of Drs. Gail Lewis and Jovan Byford. His work involves looking at issues of migration, ethnicity and diaspora, particularly with regard to Irishness, from a discursive social psychological tradition. He will shortly take up a position as a Research Associate on the Impact of Diasporas on the Making of Britain project at the University of Leicester. He is also the winner of the 2011 ASEN/Dominique Jacquin-Berdal Prize. 